\title{
PROTECTIVE EFFECT ETHANOLIC EXTRACT OF Boesenbergia pandurata (ROXB.) Schlecht. AGAINST UVB-INDUCED DNA DAMAGES IN BALB/C MICE.
}

\author{
Shanti Listyawati ${ }^{1,2}$, Sismindari $^{3 *}$, Sofia Mubarika ${ }^{4}$, Yosi Bayu Murti ${ }^{3}$
}

1Faculty of Mathematics and Natural Sciences Universitas Sebelas Maret, Jl. Ir. Sutami 36A, Surakarta Indonesia, 57126 ,

2Program of Biotechnology, Graduate School, Universitas Gadjah Mada, Yogyakarta Indonesia 55281

3Fac. of Pharmacy Universitas Gadjah Mada, Yogyakarta, Indonesia 55281

${ }^{4}$ Faculty of Medicine Universitas Gadjah Mada, Yogyakarta, Indonesia 55281

Submitted: 28-08-2014

Re vised: $20-02-2015$

Accepted: $30-03-2015$

*Corresponding author Sismindari

Email:

sismindari@ugm.ac.id

\begin{abstract}
Boesenbergia pandurata (Roxb.) Schlecht. contains bioactive compounds that have a number healthy effect including anti-oxidant and anti-carcinogenic activities. This research was carried out to examine the protective effect of $B$. pandurata extract against expression of cyclobutane pyrimidine dimers (CPDs) as marker of UVB-induced DNA damage in Balb/c mice. Dried powder of $B$. pandurata rhizomes was extracted by maceration method using $90 \%$ ethanol. The extract was quantified with pinostrobin as active marker using TLC scanner. Ethanolic extract of $B$. pandurata (EEBP) was given orally at 14 days prior UV exposure with variety doses, 0 (vehicle), 20, 40 and $60 \mathrm{mg} / \mathrm{kgBW} /$ day and continuing until termination of the experiment. Following the UVB irradiation $\left(1.4 \mathrm{~J} / \mathrm{m}^{2}\right)$, mice were sacrificed at different time points $(2,24,48$, and $72 \mathrm{~h}$ after UVB exposure). The back skin samples were collected to analyze CPDs expression by immunohistochemical method. The result showed that EEBP (contained $0.5 \%$ pinostrobin) dose was 40 and $60 \mathrm{mg} / \mathrm{kgBW} /$ day had protective activity against UVinduced DNA damage as indicated by the decrease of CPDs expression.
\end{abstract}

Key words: Boesenbergia pandurata (Roxb.) Schlecht., UVB, DNA damage, CPDs.

\section{INTRODUCTION}

The solar ultra violet (UV) radiation is main factor caused skin cancer (Katiyar, 2007). Overexposure solar UV radiation induce oxidative stress, inflammation, immunosupression, and DNA damage, which has been implicated in variety of skin damages including erythema, sunburn, scaling, dryness, premature aging, and skin cancer (Katiyar, 2007; Pérezsánchez et al., 2014). UVB radiation can be absorbed by chromophores of DNA resulting to the formation of DNA lesion primarily gyclobutane pyrimidine dimers (CPDs) and (6-4)-pyrimidine pyrimidones photoproduct (Matsumura and Ananthaswamy, 2004). These photoproducts are UVB-induced DNA lesions specific. Between various types of DNA damage, CPDs is most plentiful, difficult repaired, and have mutagenic activity (You and Szabo, 2000).

The development of chemopreventive agents and strategies on reducing the risk of $\mathrm{UV}$-induced skin cancer was required to repress this health issue (Katiyar, 2007). Naturally product compounds which posses antioxidant, anti-inflammatory, immunomodulatory, and increase DNA repair system can be exploited as ideal chemopreventive agents for skin cancer (Vaid and Katiyar, 2010). One of the natural products is come from Boesenbergia pandurata, (Roxb.) Schlecht., known as temu kunci in Indonesia, fingerroot (English) and kra-chai (Thailand). The rhizome has been used for a spice and folk medicine such as treatment of asthma and gastrointestinal disorder (Shindo et al., 2006; Tanjung et al., 2013).

Studies on the rhizomes extract of $B$. pandurata have showed cytotoxic activity (Kamkaen et al. 2006) and anti-proliferatif effect against ovarian $\left(\mathrm{CaOV}_{3}\right)$, breast (MDAMB-231 and MCF-7), cervical (HeLa) and colon (HT-29) cancer cell-lines (Jing et al., 2010). The rhizomes of B.pandurata contain bioactive compound flavonones (pinostrobin, pinocembrin, alpinetin) and chalchones (cardamonin, boesenbergin- $A$, panduratin-C, panduratin-A, hydroxypanduratin-A) 
(Cheenpracha et al., 2006; Ching et al., 2007). Boesenbergin-A has been shown to apoptosis induce against human non-small cell lung cancer (A549 cells) (Isa et al., 2012). Panduratin A, demonstrated anti-proliferative effect and induced apoptosis on human breast cancer (MCF-7) and human colon adenocarcinoma (HT-29) cell-line (Kirana, et al., 2006), this compound also could inhibit atopic dermatitis (Kim, et al., 2014). While both pinocembrin and pinostrobin showed cytotoxic effect in breast cancer (T47D) and colon cancer (WiDr) cellline (Tanjung et al., 2013). All the activity of these substances isolated from B. pandurata are correlated with chemoprevention action.

This research was carried out to examine the protective effect of EEBP against of expression cyclobutane pyrimidine dimers (CPDs) that was specific lesion of UV-induced DNA damage in Balb/c mice

\section{MATERIALS AND METHODS Plant materials}

Rhizomes of B. pandurata were collected from Kalibawang, Kulonprogo, Yogyakarta, Indonesia, and determinated by a taxonomist from Department of Pharmaceutical Biology, Faculty of Pharmacy, Universitas Gadjah Mada. These rhizomes was sliced and dried at $50^{\circ} \mathrm{C}$ then grounded to a fine powder, followed by maceration process using $90 \%$ ethanol for $72 \mathrm{~h}$, with occasional stirring. This process was repeated for three times and all the macerate obtained then evaporate using vacuum rotary evaporator to get semi solid ethanolic extract (Nihlati et al. 2008). The extract was then analyzed pinostrobin contained using TLC (Thin Layer Chromatography) and TLC scanner (Gamac TLC Scanner-3) for quantification. Isolated pinostrobin (HPLC purity of 96\%) was obtained from Organic Chemistry Laboratory, Faculty of Mathematics and Natural Sciences, Universitas Negeri Yogyakarta,

\section{Experimental animals}

Female 21 days old Balb/c mice were obtained from Integrated Research and Testing Laboratory, Universitas Gadjah Mada. These mice were fed ad libitum pellets (BRII) and drinking water. The experiment protocols were approved by the Ethical Clearence Committe of Integrated Research and Testing Laboratory,
Universitas Gadjah Mada (OR/KECLPPT/1/2011).

The mice were divided into 5 groups, control (drinking water), vehicle (solvent of $\mathrm{EEBP}+\mathrm{UVB}$ ), and three groups (EEBP with $20 ; 40$; and $60 \mathrm{mg} / \mathrm{kgBW} /$ day respectively + UVB). EEBP was given orally at 14 days prior UV exposure and continuing until termination of the experiment.

\section{UV light radiation}

The source of UV light is UVB lamps 270-290 nm wavelength (Dermatology, Medicine Faculty, Universitas Gadjah Mada). Mice were exposed to acute UVB irradiation $1.4 \mathrm{~J} / \mathrm{m}^{2}$.

\section{Skin samples collection}

At each time point $(2,24,48$, and $72 \mathrm{~h}$ after UV exposure), three mice from each group were sacrificed, dorsal skin of mice were necropsied. The skin samples $\left(3 \times 3 \mathrm{~cm}^{2}\right)$ were fixed with $10 \%$ buffered formalin and embedded in paraffin, this process referenced from standard procedure of Histology and Cytology Laboratory, Faculty of Medicine, Universitas Gadjah Mada.

\section{Detection of CPDs}

Tissue section $(5 \mu \mathrm{m})$ were cut and mounted onto poly-l-lysine coated slides and endogenous peroxidase was quenched by $0.3 \%$ hydrogen peroxide. The sections were then denaturated in $70 \mathrm{mMol} / \mathrm{L} \mathrm{NaOH}$ in $70 \%$ ethanol for $2 \mathrm{~min}$ and neutralization for $1 \mathrm{~min}$ in $100 \mathrm{mMol} / \mathrm{L}$ Tris- $\mathrm{HCl}(\mathrm{pH} 7.5)$ in $70 \%$ ethanol. Non-specific binding sites were blocked with PBS containing 10\% goat serum, followed by overnight incubating antibodies CPDs (CosmoBio). The CPDs immuno-reactivity was detected with LSAB2 System-HRP staining kit (Dako) and counterstained with Mayer's Hematoxylin.

\section{Analysis of CPDs}

Immunohistochemistry (IHC)-stained tissue were analyzed using a semi-quantitative system by image analyzer (ImageJ software). CPDs expression was interpreted in percent positive area of IHC stained. Statistic analysis was perform by ANOVA and followed by Tukey's test (SPSS 17.0). 

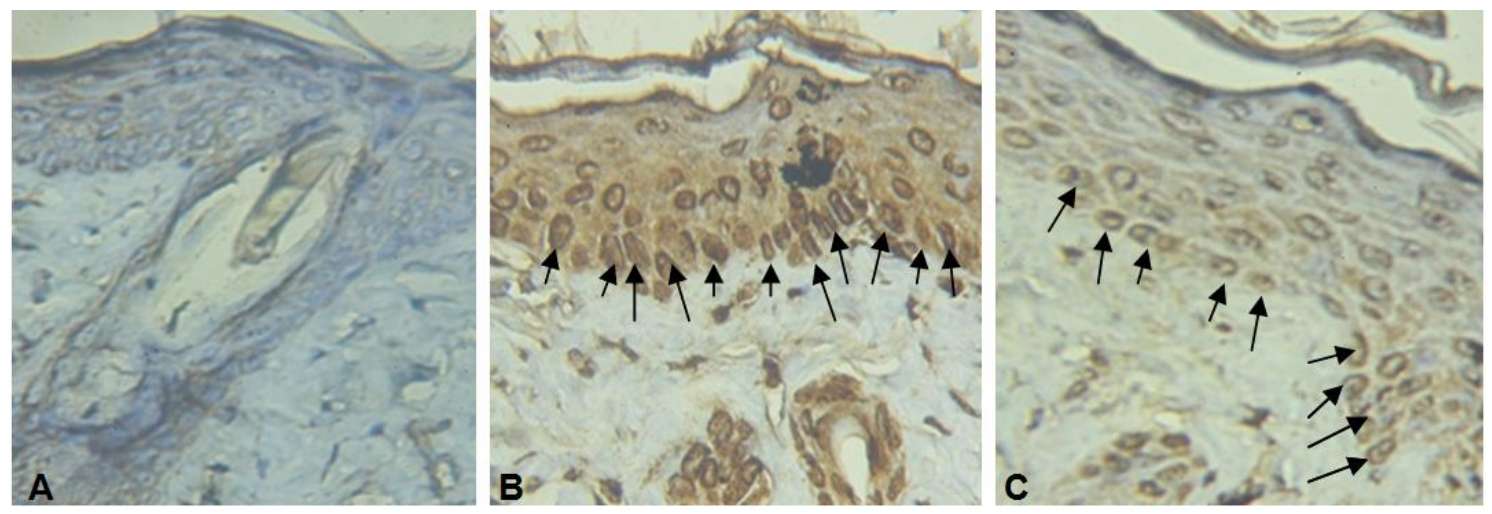

Figure 1. The observation of expression of CPDs using immunohistochemical method (original magnification 400x).

CPDs undetected on non UVB irradiation-group (A). Positively CPDs cells showed dark brown $(\rightarrow)$ found at dermal and epidermal layers in UVB treated groups only (B and $\mathrm{C})$. Treatment of EEBP could decrease CPDs expression (C). (A): control group: without UVB and EEBP, (B) vehicle: solvent of EEBP+ UVB, (C) $\mathrm{UVB}+60 \mathrm{mg} \mathrm{EEBP} / \mathrm{kg} \mathrm{BW} /$ day

\section{RESULT AND DISCUSSION}

Rhizome of B. pandurata was contained some bioactive compounds, which showed antioxidant, anti-inflammatory, and anti-cancer activities potentially used photoprotective agent (Kirana et al., 2007; Isa et al., 2012). The different condition and area on collecting of the rhizomes, may affect the variation of compounds and activity. In this study, extraction of the B. pandurata rhizome produced a dark brown semi-solid extract, bitter and aromatic smell. The ethanolic extract of Boesenbergia pandurata (EEBP) contained 0.5\% pinostrobin. The extract was given at 14 days before UVB exposure to examined chemopreventive effect against CPDs expression.

The acute exposure of UVB $\left(1,4 \mathrm{~J} / \mathrm{m}^{2}\right)$ on mice skin could induce DNA damage leading to the formation of CPDs. The dark brown color showed positively CPDs stainedcell (Figure1). The CPDs expression was found in cytoplasm and nucleus cells of epidermal and dermal layer in UVB-exposed group (Figure 1). It was showed that UVB exposure penetrated into dermal layer skin mice, this result consistent with the previous study when UVB $\left(180 \mathrm{~mJ} / \mathrm{cm}^{2}\right)$ exposed on the SKH-1 hairless, $\mathrm{C} 3 \mathrm{H} / \mathrm{HeN}$ and IL-12p40KO mice (Meeran et al., 2009; Afag et al., 2010). UV-B radiation can penetrate the skin to depth approximate 160-180 $\mu \mathrm{m}$. This rays can cross whole epidermal layer and penetrate to dermal compartment of human skin (Nichols \& Katiyar, 2010). Highest expression of CPDs showed at 2 hours after UVB exposure (Figure 2). Balb/c mice showed less sensitive to UVB irradiation than hairless mice which had the highest CPDs expression at $0.5 \mathrm{~h}$ after $180 \mathrm{~mJ} / \mathrm{cm}^{2}$ UVB irradiation on female $\mathrm{C} 3 \mathrm{H} / \mathrm{HeN}$ and IL-12p40 KO mice (Meeran et al., 2009) and at $1 \mathrm{~h}$ after a single dose of 3xMED (Minimal Erythema Dose) of Solar Simulator UV in hairless mice (Widyarini, 2006). These indicated that UVB-induced CPDs formation was influenced of wave length, intensity of radiation and animal sensitivity.

After $2 \mathrm{~h}$ UVB irradiation, on EEBP-fed mice showed CPDs expression fewer than vehicle group (solvent of EEBP + UVB) (Figure 2), it demonstrated EEBP could reduce and remove $\mathrm{CPDs}^{+}$cells rapidly in the skin of $\mathrm{Balb} / \mathrm{c}$ mice. On vehicle group, positive CPDs stained-cells (CPDs ${ }^{+}$cells) reduced $(15 \%)$ within $24 \mathrm{~h}$ after UVB exposure, and decline continued following time point of observation. These $\mathrm{CPDs}^{+}$cells persisted up to $72 \mathrm{~h}$ post-UVB. This finding supported the previously reported studies on UV inducedhairless mice (Zattra et al., 2009). CPDs expression in group with $20 \mathrm{mg} / \mathrm{kgBW} /$ day EEBP treatment were not significantly 


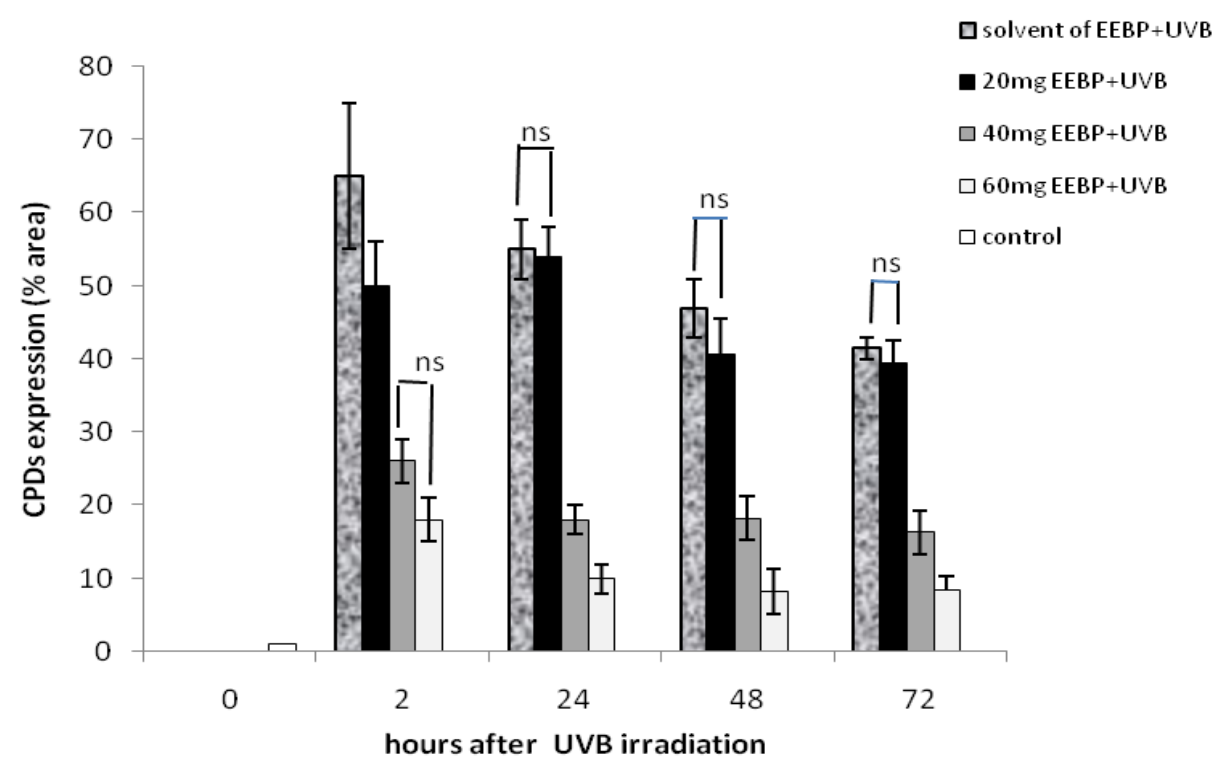

Figure 2. The representation of semi-quantitative analyze of effect of EEBP against CPDs expression.

CPDs positive (CPDs+) cells are expressed as percent area CPDs+. After 2 hours UVB irradiation, CPDs expression on EEBP-fed mice showed fewer area than vehicle group (solvent of EEBP +UVB), EEBP dose was 40 and $60 \mathrm{mg} / \mathrm{kg} \mathrm{BW/day} \mathrm{decreased} \mathrm{CPDs} \mathrm{expression} \mathrm{until} 78 \%$ and $82 \%$ at 72 hours post-UVB. CPDs were undetectable $(0 \%)$ on control group at all time point observation. (ns: not significant at the same time point; $\mathrm{p}<0.05)$.

different with vehicle $(\mathrm{P}<0.05)$ at 24,48 , and $72 \mathrm{~h}$ after UVB irradiation, while groups with 40 and $60 \mathrm{mg} / \mathrm{kg} \mathrm{BW/day} \mathrm{EEBP} \mathrm{treatment} \mathrm{could}$ decrease of CPDs expression $60 \%$ and $72 \%$ from the vehicle value at $24 \mathrm{~h}$ after UVB irradiation, $78 \%$ and $82 \%$ respectively at $72 \mathrm{~h}$ after UVB irradiation. The EEBP activity however, has slightly less activity than isoflavone equol, since this compound was able to reduce $\pm 47 \%$ of the CPDs expression at 24 hours and complete disappeared at $168 \mathrm{~h}$ after UVB irradiation (Widyarini, 2006). The decrease of CPDs expression seemed to be caused by DNA repair activity through nucleotide excision repair. When DNA repair was limited, DNA damage were retained in the genome, therefore caused mutations and tumor formation (Marrot \& Meunier, 2008). Therefore, both EEBP dose (40 and 60 $\mathrm{mg} / \mathrm{kgBW} /$ day) showed protective effect against UVB induced DNA damage. This result were in accordance with previous studies, which indicated that natural diet agents including fruits, vegetables, and spices had ability to repress UV-induced skin cancer through remove or decrease the DNA damage. Acceleration of UV-induced CPDs removal were demonstrated by other natural compounds from extracts of Polypodium leucotomos (Zattra et al., 2009), Punica granatum fruits (Afag et al., 2010), green tea polyphenol (Katiyar et al., 2007; Roche et al., 2010), and luteolin (Wolfle et al., 2011). The mechanism of decreasing CPDs might be through antioxidant activity, increasing IL-12 (cytokine interfere formation of CPDs), p53 and p21 protein (Katiyar, 2007; Zattra et al., 2009; Afag et al., 2010; Wolfle et al., 2011). B. pandurata rhizome has been reported contain essential oil, pinostrobin, alpinetin, pinocembrin, cardamonin, boesenbergin, panduratin, and others (Ching et al., 2007), they might be contribute and affect on signaling pathway of DNA repair activity and therefore could decrease, inhibit and remove formation of CPDs. Pinostrobin, a flavonoid from $B$. pandurata has been reported to demonstrate antioxidant activity (Shindo, et al., 2006; Nihlati et al., 2008). It might be contribute to prevent CPDs formation was like mechanism of 
flavonoid lutein, through free radical scavenging activity.

The previous studies demonstrated that orally treatment of EEBP exerts anti-wrinkling, moisturizing effects, and prevent of tumorigenesis (Kim, et al., 2012; Listyawati et al., 2012). In addition the extract was reported safe for consumption as in vivo studies showed no significant changes in the body weight of EEBP fed rats. Furthermore, all haematological and histopathological parameters used to evaluate the toxicity effect did not show any adverse changes (Saraithong et al., 2012). Those results were suggest that EEBP showed potential as an effective systemic photoprotective agent for prevention of UVBinduced skin damages.

\section{CONCLUSION}

The result of study indicated that oral administration of EEBP 40 and 60 $\mathrm{mg} / \mathrm{kgBW} /$ day could protect UVB-induced DNA damages through reduce CPDs formation. The extract could be more studied to clarify a functional agent which has photoprotective effect. Clinical studies are also required to characterize the beneficial effects of dietary EEBP on the photodamage of human skin.

\section{ACKNOWLEDGEMENT}

This study was supported grant from Research and Development Department of Health Ministry, Republik Indonesia (HK.06.01/1/1693/2012) and PNBP Universitas Sebelas Maret Surakarta (501/UN27.11/PN/2014). We thank to Prof. Dr. Sri Atun for providing the isolated pinostrobin from B. pandurata and Nita Etikawati M.Si to technical assistance on this research.

\section{REFERENCES}

Afaq F., Khan N., Syed DN., Mukhtar H., 2010. Oral Feeding of Pomegranate Fruit Extract Inhibits Early Biomarkers of UVB Radiation-Induced Carcinogenesis in SKH-1 Hairless Mouse Epidermis. J. Photochem. Photobiol. B: Biol. 86(6):1318-1326.

Cheenpracha S., Karalai C., Ponglimanont C., Subhadhirasakul S., Tewtrakul S., 2006.
Anti-HIV-1 protease activity of compounds from Boesenbergia pandurata. J. Bioorg. Med. Chem. 14(6): 1710-1714.

Ching AYL., Wah TS., Sukari MA., Rahmani LM., Khalid K. 2007. Characterization of flavonoid derivatives from Boesenbergia rotunda (L.) Malay. J. Anal. Sci. 11(1): 154159.

Isa NM., Abdul AB., Abdelwahab SI., Abdullah R., Sukari MA., et al., 2013. Boesenbergin A, a chalcone from Boesenbergia rotunda induces apoptosis via mitochondrial dysregulation and cytochrome c release in A549 cells in vitro: Involvement of HSP70 and $\mathrm{Bcl} 2 / \mathrm{Bax}$ signalling pathways. J. Fung. Foods 5: 87-97.

Jing LJ., Mohamed M., Rahmat A., Bakar MFA. 2010. Phytochemicals, antioxidant properties and anticancer investigations of the different parts of several gingers species (Boesenbergia rotunda, Boesenbergia pulchella var. attenuata and Boesenbergia armeniaca). J. Med. Plant. Res. 4(1): 27-32.

Kamkaen N., Wilkinson JM., Cavanagh HMA., 2006. Cytotoxic Effect of Four Thai Edible Plants on Mammalian Cell Proliferation. I. Thai Pharma. Health Sci. 1(3):189-195.

Katiyar S., Elmets CA., Katiyar SK., 2007. Green tea and skin cancer: Photoimmunology, angiogenesis and DNA repair. J. Nutr. Biochem.18: 287-296.

Katiyar SK., 2007. Interleukin-12 and photocarcinogenesis. Toxicology and Applied Pharmacology.224: 220-227

Kim S., Oh HI., Hwang JK., 2012. Oral Administration of Fingerroot (Boesenbergia pandurata) Extract Reduces Ultraviolet Binduced Skin Aging in Hairless Mice. Food Sci. Biotech. 21(6): 1753-1760.

Kim MS., Pyun HB., Hwang JK, 2014. Panduratin A, an activator of PPAR $-\alpha / \delta$, suppresses the development of oxazolone-induced atopic dermatitis-like symptoms in hairless mice. Life Sciences. 100(1): 45-54

Kirana C., Jones GP., Record .R., McIntosh GH. 2007. Anticancer properties of panduratin A isolated from Boesenbergia pandurata (Zingiberaceae). J. Nat. Med. 61:131-137 
Listyawati S., Sismindari Mubarika S., Murti, YB., 2012. Aktivitas Kemoprevensi Ekstrak Temu Kunci (Boesenbergia pandurata) pada Karsinogenesis Kulit Mencit Balb/c Terinduksi Ultra Violet, Seminar Nasional IX, Biologi, Sains, Lingkungan, dan Pembelajarannya dalam Upaya Peningkatan Daya Saing Bangsa, Surakarta: Program Studi pendidikan Biologi, FKIP, Universitas Sebelas Maret Surakarta, hal. 612-616.

Nihlati I., Rohman A., Hertiani T., 2008. Daya Antioksidan ekstrak etanol rimpang temu kunci (Boesenbergia pandurata (Roxb.) Schlecth.) dengan metode radikal DPPH $(1,1=$ difenil-2-pikrilhidrasil. Majalah Obat Tradisional. 13:45.

Marrot L., Meunier JR., 2008. Skin DNA photodamage and its biological Consequences. J. Am. Acad. Dermatol. 58: S139-148.

Matsumura Y., Ananthaswamy HN., 2004. Toxic effects of ultraviolet radiation on the skin. Tox. Appl. Pharmacol. 195(3): 298-308.

Meeran SM., Akhtar S., Katiyar SK. 2009. Inhibition of UVB-Induced Skin Tumor Development by Drinking Green Tea Polyphenols is Mediated Through DNA Repair and Subsequent Inhibition of Inflamation. J. Invest. Dermatol. 129 (5): 1258-1270.

Nichols JA., Katiyar SK., 2010. Skin photoprotection by natural polyphenols: Anti-inflammatory, anti-oxidant and DNA repair mechanisms. Arch. Dermatol. Res. 302(2): 71.

Pérez-sánchez A., Barrajón-catalán E., Caturla N., Castillo J., Benavente-garcía O., 2014. Protective effects of citrus and rosemary extracts on UV-induced damage in skin cell model and human volunteers. J. Photochem. Photobiol. B: Biol. 136: 12-18.

Roche M., Seagrove S., Mehta A., Divekar P., Campbell S., Curnow A. 2010. Using natural dietary sources of antioxidants to protect against ultraviolet and visible radiation-induced DNA damage: an investigation of human green tea ingestion. J. Photochem. Photobiol. B: Biol. 101(2): 169-173.

Saraithong P., Saenphet S., Saenphet K., 2010. Safety Evaluation of Ethanol Extracts from Bosenbergia rotunda (L.) Mansf. in Male Rats. Trends Research in Science and Technology. 2 (1): 19-22

Shindo K., Kato M., Kinoshita A., Kobayashi A., Koike Y., 2006. Analysis of antioxidant activities contained in the Boesenbergia pandurata Schult. Rhizome. Biosci. Biotech. Biochem.70(9): 2281-2284.

Tanjung M., Tjahjandarie TS., Sentosa MH., 2013. Antioxidant and cytotoxic agent from the rhizomes of Kaempferia pandurata. Asian Pac. J. Tropic. Dis. 3(5): 401-404.

Vaid M., Katiyar SK., 2010. Molecular mechanisms of inhibition of photocarcinogenesis by silymarin, a phytochemical from milk thistle (Silybum marianum L. Gaertn). Int. J. Oncol. 36(5): 1053-1060.

Widyarini S., 2006. Protective effect of the isoflavone equol against DNA damage induced by ultraviolet radiation to hairless mouse skin. J. Vet. Sci., 7(3): 217-223

Wölfle U., Philipp R., Esser PR., SimonHaarhaus B., Martin SF. Lademann J., Schempp CM., 2011. UVB-induced DNA damage, generation of reactive oxygen species, and inflammation are effectively attenuated by the flavonoid luteolin in vitro and in vivo. Free Radic. Biol. Med. 50: 1081-1093.

You Y., Szabo PE., 2000. Cyclobutane pyrimidine dimers form preferentially at the major p53 mutational hotspot in UVB-induced mouse skin tumors. Carcinogenesis. 21(11): 2113-2117

Zattra E., Coleman C., Arad S., Helms E., Levine D., et al., 2009. Polypodium leucotomos Extract Decreases UV-Induced Cox-2 Expression and Inflammation, Enhances DNA Repair, and Decreases Mutagenesis in Hairless Mice. AJP. 175(5): 19521960. 